\title{
Defeating the Devil in the Waste: Remediation of Infectious Covid-19 Waste
}

\section{Sachin Kumar ${ }^{1}$ and Pinky Kain ${ }^{2 *}$ \\ ${ }^{1}$ Director/Founder, Viresco Technologies LLP, Roorkee, Uttarakhand, India \\ ${ }^{2}$ Principal Investigator/DBT Welcome Trust India Alliance Fellow, Laboratory of \\ Neurogenetics, Regional Centre for Biotechnology, NCR Biotech Science Cluster, \\ Faridabad, Haryana, India}

*Corresponding Author: Pinky Kain, Principal Investigator/DBT Welcome Trust India Alliance Fellow, Laboratory of Neurogenetics, Regional Centre for Biotechnology, NCR Biotech Science Cluster, Faridabad, Haryana, India.
Received: June 29, 2020

Published: July 30, 2020

(C) All rights are reserved by Sachin Kumar and Pinky Kain.

DOI: $10.31080 /$ ASNE.2020.03.0207

Recently, many countries have been able to defeat Covid-19 but USA, India, Brazil and many others are still facing an extreme health crisis with a shaken economic. There has been a rise in testing, but with such a huge population load in countries like India, the fight is even more difficult. Every body's plans are gone for a toss so as the economic and developmental plans but still one as to assure healthy livelihood and well-being of people post Covid-19.

Pictures of waste floating in the sea and rivers, scattered waste outside the garbage bins and stray animals carrying mask in their mouths are in circulation on social media. Low-income countries with weak health systems, crowded megacities and large populations of impoverished people are facing huge challenge to dispose Covid-19 biomedical waste generated every day. Not every country has the same ability to protect people and environment, so it is everybody's responsibility to become sagacious and defeat the virus as well as control its further spread by taking preventive measures. Failure to pay attention to the Covid-19 waste management may result in risk of poor outcomes during the pandemic which is far higher among those with comorbidities.

The Covid-19 infectious-biomedical waste generated from the health care and research activities are posing a huge invisible threat. The waste containing many deadly microorganisms, their toxins and particularly Corona Virus are posing a risk of infection relapse and occurrence of future infection waves. Workers who are involved in taking care of this waste are at risk of getting exposed to Covid-19 and other dangerous biological agents by punctures/ cuts (contaminated sharps), skin-mucous contact/projection of blood or biological fluids, ingestion or inhalation of contaminated particles.

Research activities produce mass scale single use waste including metal, plastic and glass lab consumables. Infectious waste originating from health care facilities comes from various hospital services [1] (contaminated surgical drapes, gauzes, compresses, bandages, personal protection equipment, sharps, single-use care kits and surgical instruments, plastic or glass lab consumables, hemodialysis waste and waste containing fluids). Given the range of waste generated every day, management of infectious biomedical waste should become an integral part of our health care systems and should not be ignored at any level. Currently the primary concern is to use easy, inexpensive and eco-friendly methods to handle infectious biomedical waste and reduce the load in our surroundings for well-being of people.

Confronting Covid-19 infectious-biomedical waste generated in hospital and at the research centers, proper segregation and management of this waste is paramount. Becoming waste wise and controlling the biological risk at the segregation facilities to prevent cross-contamination can help combating Covid-19. The disposal of biohazardous waste should be done following prior treatments. Many options that could prove useful for the treatment of biomedical waste are available and should be opted in such a health crisis [2-4]. 
Various methods to be considered are, use of chemicals disinfectants such as Sodium hypochlorite, dissolved chlorine dioxide, peracetic acid, hydrogen peroxide, dry inorganic chemical and ozone. Most chemical processes are water-intensive and require neutralizing agents. Thermal processing utilizing heat to disinfect waste including low-heat $\left(93-177^{\circ} \mathrm{C}\right.$, use of steam, hot water, or electromagnetic radiation, autoclave and microwave) and high heat systems $\left(540^{\circ} \mathrm{C}\right.$ and $8300^{\circ} \mathrm{C}$, use of incinerator and hydroclaving, pyrolysis - oxidation, plasma pyrolysis, induction and lasebased pyrolysis; Datta., et al. [5]). The other processes are mechanical processes involving compaction to reduce the volume of waste and shredding to destroy plastic and paper waste to prevent their reuse [2]. Irradiation processes exposing waste to ultraviolet or ionizing radiation in an enclosed chamber. Biological processes with the use of biological enzymes for treating medical waste. Biological methods for disposal include an emerging system called "Bioconverter" (Biomedical Disposal, Inc.). It uses a solution of enzyme to decontaminate medical waste, and the resulting sludge goes through an extruder used to remove water for sewage disposal sending the solid waste to landfill.

The complete decontamination of biomedical waste cannot be guaranteed. In place of an autoclave, new technologies like STERIPLUS $^{\text {тм }}$ system (from Tesalys') can be used for better results. The system ensures perfect penetration of the steam through the waste and consequently, more significant neutralization of any biological risk. One need to understand and segregate the waste first and choose an appropriate method for the waste treatment.

Bio-medical waste management need committed government backing, good practices followed by both health-care workers and health care facilities, continuous monitoring of practices, and strong administration. It is our fundamental right to live in clean and safe environment. Segregation of waste at source and waste reduction should be of prime importance for management. Lack of education, awareness and trained personnel to manage the waste and paucity of the funds available to proper waste management system are currently causing biggest challenges that hospital and research centers are facing during the implementation of biomedical waste.

\section{Funding Source}

This work is funded by the DBT Wellcome Trust India Alliance Intermediate grant to P.K. (grant number IA/I/15/2/502074).

\section{Bibliography}

1. https://celitron.com/en/types-of-biomedical-waste-definition

2. https://vikaspedia.in/energy/environment/waste-management/bio-medical-waste-management/treatment-of-biomedical-waste

3. https://terragon.net/pharos-blog/medical-waste/

4. https://www.malsparo.com/treat2.htm

5. P Datta., et al. "Biomedical waste management in India: Critical appraisal”. Journal of Lab Physicians 10 (2018): 6-14.

\section{Assets from publication with us}

- Prompt Acknowledgement after receiving the article

- Thorough Double blinded peer review

- Rapid Publication

- Issue of Publication Certificate

- High visibility of your Published work

Website: www.actascientific.com/

Submit Article: www.actascientific.com/submission.php Email us: editor@actascientific.com

Contact us: +919182824667 